INOBIS: Jurnal Inovasi Bisnis dan Manajemen Indonesia

Volume 1, Nomor 2, Maret 2018

Dwi Kurniawan; Sumarni

\title{
Identifikasi Budaya Organisasi Dan Keterampilan Manajemen Untuk Memelihara Eksistensi Usaha Kreatif Batik Jambi Di Kota Jambi
}

\author{
Oleh: \\ Dwi Kurniawan \\ Universitas Jambi / dwi.kurniawan13@unja.ac.id \\ Sumarni \\ Universitas Jambi / mm_sumarni@yahoo.com
}

\begin{abstract}
Abstrak
Penelitian ini berjudul Identifikasi Budaya Organisasi dan Keterampilan Manajemen Untuk Memelihara Eksistensi Usaha Kreatif Batik Jambi di Kota Jambi. Objek penelitian yaitu para pengusaha batik yang berada di Kota jambi dengan jumlah responden sebanyak 20 unit usaha. Penelitian ini menggunakan pendekatan yang dikembangkan oleh Cameron and Quinn yang dikenal dengan Competing Value Framework (CVF) dengan dua pengukuran yaitu Organizational Assessment Culture Instrument (OCAI) untuk mengukur profil budaya, dan Management Skills Assessment Instrumen (MSAI) untuk mengukur kompetensi manajerial para manajemen. Dari hasil penelitian diketahui bahwa tipe budaya yang ingin ditingkatkan proporsinya adalah tipe budaya Adhocracy dan budaya Market yaitu masingmasing bertambah sebesar 3,42 dan 8,86. Perubahan pada proporsi tipe budaya organisasi usaha kreatif pengrajin batik secara umum memperlihatkan bahwa tipe budaya yang diharapkan akan mendominasi adalah tipe Budaya Adhocracy dan Budaya Market. Untuk Profil Keterampilan Manajemen ditemukan bahwa kegiatan usaha batik di Kota Jambi, para manajemen memiliki kecenderungan melakukan keempat profil budaya, baik budaya yang bersifat Clan, Adhocracy, Market, dan Hierarchy.
\end{abstract}

Kata kunci: Profil Budaya, Competing Value Framework (CVF), Organizational Assessment Culture Instrument (OCAI), Management Skills Assessment Instrumen (MSAI), Batik Jambi.

\section{Pendahuluan}

\subsection{Latar Belakang}

Pemahaman mengenai budaya organisasi adalah sangat penting guna memahami apa yang sedang terjadi dalam organisasi, bagaimana menjalankannya dan cara untuk memperbaikinya (Schein, 1992). Budaya organisasi didefinisikan sebagai kumpulan dari asumsi-asumsi, keyakinan-keyakinan, dan norma-norma atau perilaku-perilaku normal yang dimiliki oleh para anggota organisasi. Para ahli mengakui bahwa budaya organisasi memiliki pengaruh yang kuat terhadap kinerja dan efektivitas jangka panjang dari organisasi. Cameron dan Quinn (2011) mengemukakan bahwa apa yang membedakan perusahaan-perusahaan yang sukses dari perusahaan-perusahaan lainnya adalah terletak pada budaya organisasi mereka.

Meskipun pentingnya budaya organisasi telah dipahami secara luas oleh para pengelola organisasi, namun beberapa hasil kajian menemukan bahwa kebanyakan dari perusahaan-perusahaan tidak memiliki tipe budaya organisasi yang jelas. Sejumlah kajian mengungkapkan kecenderungan perusahaan sekarang ini memiliki budaya pasar, diikuti budaya hirarki atau birokrasi dan budaya klan, sementara budaya adhocracy atau budaya kewirausahaan hampir tidak ditemukan dalam berbagai kajian. 
INOBIS: Jurnal Inovasi Bisnis dan Manajemen Indonesia

Volume 1, Nomor 2, Maret 2018

Dwi Kurniawan; Sumarni

Diantara pendekatan yang relevan untuk mengenali budaya organisasi, bahkan juga untuk merubah budaya organisasi, adalah apa yang oleh Cameron dan Quinn (2011) konsepsikan sebagai The Competing Value Framework (CVF). Pendekatan ini dikembangkan dengan mengintegrasikan berbagai ukuran yang lazim digunakan untuk mengukur efektivitas organisasi. Dua dimensi dengan empat kuadran dikembangkan yang mencerminkan tipologi dari budaya organisasi. Dimensi pertama membedakan efektivitas organisasi dari segi fleksibilitas dan diskresi dengan stabilitas dan control. Dimensi kedua membedakan efektivitas dari orientasi internal dan orientasi eksternal. Tiap dimensi merupakan nilai-nilai yang berkompetisi terhadap dimensi lainnya. Keempat kuadran yang dilahirkan dari ke dua dimensi tersebut mencerminkan nilai-nilai inti yang dimiliki oleh organisasi, yakni budaya klan, budaya adhocracy, budaya hirarki, dan budaya pasar. Kekuatan budaya dari organisasi dari tiap tipe budaya dapat dikenali dari enam dimensi yang relevan, yaitu: karakteristik dominan, kepemimpinan organisasi, manajemen pegawai, perekat organisasi, penekanan strategis, dan kriteria sukses. Sebagai ilustrasi, dari dimensi kepemimpinan organisasi, misalnya, untuk budaya klan para pemimpin menunjukkan perilaku sebagai mentor, sebaliknya dalam budaya pasar para pemimpin adalah berorientasi hasil.

Kekuatan budaya dari organisasi untuk tiap tipe budayanya harus diiringi dengan kompetensi dan keterampilan manajemen dari para anggota organisasi, baik pada level pelaksana maupun pada level manajerial. Dengan demikian, harus ada kecocokan atau kongruensi antara tiap tipe budaya yang dimiliki oleh organisasi dengan keterampilan personal dari para pengelola.

Usaha batik jambi merupakan di antara kelompok usaha yang tergolong usaha industri rumahan (home industry) yang telah eksis sejak awal tahun 1970-an dan berdasarkan data dari Dinas Perindustrian Provinsi Jambi (2013) terdapat sebanyak 56 usaha batik dengan mempekerjakan sebanyak 283 karyawan. Dalam kurun waktu sekitar 40-an tahun, perkembangan usaha batik belum menunjukkan pertumbuhan yang signifikan. Berbagai permasalahan yang teridentifikasi dari lambatnya perkembangan usaha batik dapat dilihat dari dua aspek, yakni aspek lingkungan eksternal dan aspek lingkungan internal. Dari aspek eksternal, usaha batik dihadapkan dengan berbagai kekuatan, seperti lingkungan pemasok, kehadiran produk subsitusi, misalnya dari usaha batik modern, serta rivalitas dari sesama usaha batik. Dari aspek internal, permasalahan utama masih didominasi oleh rendahnya kreativitas dan kemampuan sumberdaya manusia.

Merujuk pada berbagai pandangan teoritik dan berbagai pengalaman dari perusahaan yang berhasil, terutama perusahaan yang keberhasilannya bukan berbasis pasar melainkan pada sesuatu yang tidak beruwujud yang berasal dari dalam organisasi, maka sangat relevan untuk mengkaji lebih lanjut mengenai budaya organisasi. Kekuatan budaya organisasi merupakan sumber keunggulan bersaing yang dapat mengalahkan kekuatan pasar. Hal ini berarti bahwa bila usaha batik jambi ingin tumbuh dan berkembang dalam lingkungan yang sangat kompetif maka harus ada kompetensi inti yang lestari, yakni sumberdaya dan kapabilitas yang terbedakan. Untuk itu penelitian ini ingin mengenali dan menilai profil budaya dari organisasi-organisasi yang tergabung dalam usaha batik Jambi, mengkaitkan dengan kompetensi personal dari pengelola dan karyawan untuk melihat kongruensinya.

\subsection{Rumusan Masalah}

Survey awal menemukan bahwa kebanyakan pengusaha memiliki nilai-nilai dan keyakinan-keyakinan personal dalam menjalankan bisnis, tetapi tidak mengenali dengan jelas tipe budaya yang mereka miliki. Identifikasi mengenai tipe budaya adalah penting sebagai 
INOBIS: Jurnal Inovasi Bisnis dan Manajemen Indonesia

Volume 1, Nomor 2, Maret 2018

Dwi Kurniawan; Sumarni

sarana untuk membangun atau merubah budaya di masa mendatang yang sesuai dengan tuntutan dari lingkungan yang semakin kompetitif dan dinamis.

Diantara pendekatan yang dapat digunakan untuk menilai budaya organisasi adalah pendekatan The Competing Value Framework (Cameron dan Quinn, 2011), yang mengenali empat tipe budaya organisasi, yakni budaya klan, budaya adhocracy, budaya hirarki, dan budaya pasar. Pendekatan CVF menjelaskan bahwa tiap-tiap tipe budaya haruslah kongruen atau cocok dengan perilaku-perilaku dari para anggota organisasi, termasuk ketrampilan manajemen personal dari para pegawai. Kecocokan antara ketrampilan manajemen personal dari pegawai dengan tipe budaya merupakan kekuatan yang memungkinkan perusahaan memiliki kemampuan untuk menghadapi berbagai tantangan dari lingkungan dan mengintegrasikan aspek-aspek internal organisasi.

Berdasarkan paparan di atas, beberapa pertanyaan pokok dalam penelitian ini diungkapkan berikut ini:

1. Bagaimana profil budaya saat ini dan harapan dari organisasi usaha batik yang ada di Kota Jambi?

2. Bagaimana profil ketrampilan manajemen dari para karyawan dari usaha batik yang ada di Kota Jambi?

\subsection{Tujuan Penelitian}

1. Untuk mengetahui profil budaya saat ini dan harapan organisasi usaha batik yang ada di Kota Jambi.

2. Untuk mengetahui profil ketrampilan manajemen dari para karyawan dari usaha batik yang ada di Kota Jambi

\section{Kajian Pustaka}

\subsection{Budaya Organisasi}

Schein (1999:200) mendefinisikan budaya sebagai sebuah pola dari asumsi-asumsi dasar yang dimiliki yang dipelajari oleh kelompok dalam memecahkan masalah adaptasi eksternal dan integrasi internal yang telah berjalan dengan baik untuk dianggap sebagai sesuatu yang sahih dan, karena itu, diajarkan kepada para anggota baru sebagai cara yang benar untuk mempersepsikan, memikirkan, dan merasakan sehubungan dengan masalahmasalah tersebut.

Mullins (1999:53) mendefinisikan budaya organisasi sebagai kumpulan tradisi, nilai, keyakinan, kebijakan, dan sikap yang merupakan sebuah konteks yang tersebar luas bagi segala sesuatu yang dilakukan orang dan dipikirkan orang dalam organisasi.

Dari berbagai definisi mengenai budaya maka dapat dianggapkan bahwa para ahli memiliki pandangan umum yang sama yang menyatakan bahwa budaya organisasi melibatkan keyakinan-ketakinan, sikap-sikap, dan nilai-nilai. Nilai-nilai tersebut membantu para pegawai memahami bagaimana mereka berperilaku dalam organisasi.

\subsection{Pentingnya Budaya Organisasi}

Schein (1999:110) menyatakan bahwa budaya organisasi adalah lebih penting dalam era sekarang ini dibandingkan dengan masa lampau. Peningkatan persaingan, globalisasi, 
INOBIS: Jurnal Inovasi Bisnis dan Manajemen Indonesia

Volume 1, Nomor 2, Maret 2018

Dwi Kurniawan; Sumarni

merger, akuisisi, aliansi dan berbagai perkembangan organisasi semakin menuntun arti pentingnya pemahaman mengenai budaya organisasi, misalnya dalam melakukan koordinasi dan pengintegrasian lintas unit-unit organisasi guna memperbaiki efisiensi, kualitas, pabrikasi dan penyampaian produk dan jasa.

Mullins (1999:807) mengemukakan bahwa budaya organisasi membantu menjelaskan kenapa berbagai kelompok yang berbeda mempersepsikan sesuatu dengan cara mereka dan melakukan sesuatu yang berbeda dari kelompok lain. Budaya juga dapat membantu mengurangi kompleksitas dan ketidakpastian. Budaya memberikan konsistensi dalam sudut pandang dan nilai-nilai, dan memungkinkan proses pengambilan keputusan, koordinasi dan kontrol. Kekuatan sebuah budaya memiliki hubungan dengan kinerja dari organisasi.

\subsection{Tipologi Budaya Organisasi}

Para ahli memiliki pandangan yang berbeda mengenai tipe dan dimensi dari budaya organisasi. Salah satu alasan mengenai hal tersebut adalah karena budaya organisasi merupakan konsep yang sangat luas. Ia melibatkan sekumpulan faktor yang kompleks, saling berhubungan, komprehensif, dan rancu (Cameron dan Quinn (2011:36). Sebagai akibatnya, ia tidak akan pernah mencantumkan setiap faktor yang relevan dalam melakukan diagnosa dan penilaian mengenai budaya organisasi.

Pandangan tipologi budaya yang dikemukakan oleh Hellriegel, Slocum, dan Woodman (2001) secara luas dikemukakan oleh Cameron dan Quiin (2011) dalam mendiagnosis budaya organisasi. Cameron dan Quinn mengembangkan pendekatan untuk menilai budaya organisasi dan dikenal sebagai The Competing Value Framework (CVF). Pendekatan CVF didasarkan pada dua dimensi utama. Dimensi pertama menekankan fokus organisasi (internal dan eksternal), sementara dimensi kedua membedakan antara dimensi stabilitas dan kontrol dengan fleksibilitas dan diskresi, seperti terlihat pada gambar berikut.

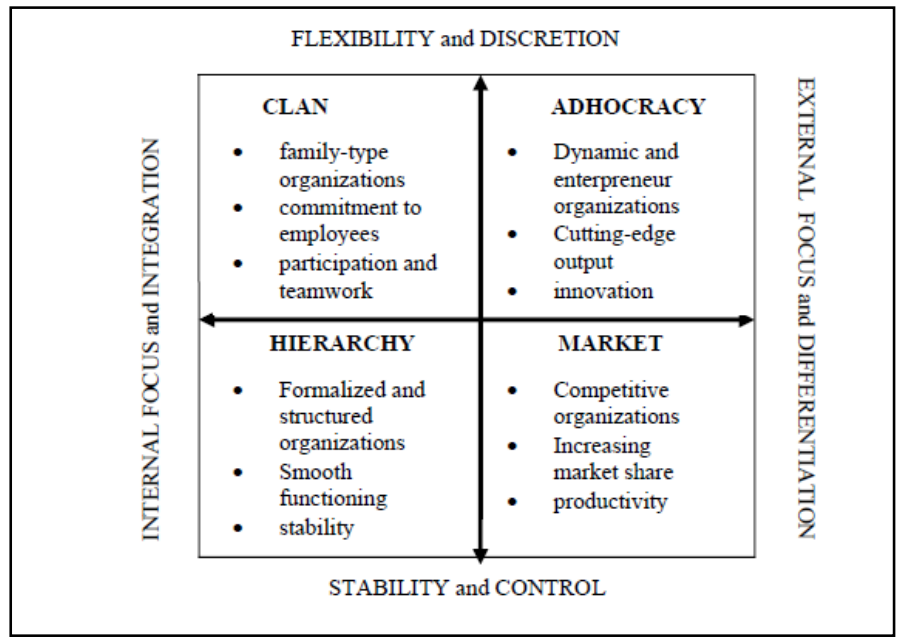

\section{Gambar 1. The Competing Values Framework (Cameron dan Quiin, 2011)}

Gambar 1. di atas memperlihatkan bahwa nilai-nilai budaya ditunjukkan dalam empat kuadran, yakni budaya klan, budaya adhocracy, budadaya hirarki, dan budaya pasar. Seperti terlihat di dalam kuadran, budaya klan dicirikan oleh organisasi yang bertipe keluarga, komitmen terhadap pegawai, dan partisipasi dan kerja tim; budaya adhocracy dicirikan oleh organisasi kewirausahaan dan dinamis, menjadi yang terdepan, dan inovasi; budaya hirarki 
INOBIS: Jurnal Inovasi Bisnis dan Manajemen Indonesia

Volume 1, Nomor 2, Maret 2018

Dwi Kurniawan; Sumarni

yang dicirikan oleh organisasi yang terstruktur dan sangat formal, kelancaran pelaksanaan fungsi, dan stabilitas; sementara buaya pasar dicirikan oleh organisasi yang kompetitif, peningkatan bagian pasar, dan produktivitas.

Selanjutnya, Cameron dan Quinn (2011) menyatakan bahwa hampir semua organisasi memiliki ke empat nilai-nilai budaya dimaksud, namun dengan dominansi dari tiap-tiap nilai yang berbeda. Sebagai ilustrasi, ada organisasi yang memiliki nilai-nilai yang lebih didominasi oleh budaya hirarki, misalnya di kebanyakan sektor pemerintahan.

\subsection{Keterampilan Manajemen}

Perilaku personal dari para anggota organisasi adalah sangat penting dalam pengimplementasian dari budaya organisasi. Perubahan budaya pada akhirnya sangat tergantung pada penerapan perilaku-perilaku oleh para karyawan dalam organisasi yang menguatkan nilai-nilai budaya yang konsisten dengan budaya yang dipraktikkan. Adalah mungkin untuk mengenali strategi dan aktivitas yang dirancang untuk menghasilkan perubahan, namun bila tidak diiringi dengan proses perubahan personal, kemauan individu untuk mengupayakan perilaku-perilaku baru, dan perubahan kompetensi manjerial, maka budaya fundemental dari organisasi tidak akan berubah.

Cameron dan Quinn (2011) mengenali ketrampilan dan kompetensi manajemen yang sangat penting bagi dimiliki oleh para anggota organisasi, yang cocok dengan kerangka nilainilai budaya. Cameron dan Quinn (2011) selanjutnya mengemukakan 12 kategori kompetensi berikut ini.

Ketrampilan Klan. Keterampilan budaya klan meliputi (1) pengeleloaan tim, yakni ketrampilan memfasilitasi timkerja yang efektif, terpadu, berfungsi lancar, dan kerkinerja tinggi; (2) ketrampilan mengelola hubungan interpersonal, yakni memfasilitasi hubungan iterpersonal yang efektif, termasuk pemberian feedback yang mendukung, mendengan, dan pemecahan masalah interpersonal; (3) ketrampilan mengembangkan orang lain, yakni membantu para individu untuk memperbaiki kinerja mereka, memperluas kompetesi, dan mendapatkan kesempatan pengembangan diri.

Ketrampilan Adhocracy. Ketrampilan budaya yang meliputi (1) pengelolaan inovasi, yakni mendorong para individu untuk berinovasi, memperluas alternatif, menjadi lebih kreatif, dan memfasilitasi penciptaan ide baru; (2) pengelolaan masa depan, yakni mengkomunikasikan visi yang jelas mengenai masa depan dan memfasilitasi pencapaiannya; (3) pengelolaan upaya perbaikan terus-menerus, yakni memperkuat orientasi ke arah perbaikan terus menerus, felksibilitas, dan perubahan produktif di antara para indivdiu dalam kehidupan bekerja mereka.

Ketrampilan Pasar. Keterampilan budaya pasar meliputi (1) pengelolaan kemampuan bersaing, yakni memperkuat kemampuan bersaing dan orientasi agresif ke arah yang melebihi para pesaing; (2) meng-energikan para pegawai, yakni memotivasi dan menginspirasikan para individu untuk proaktif, meluangkan usaha ekstra, dan kerja keras; (3) pengelolaan layanan konsumen, yakni memperkuat orientasi ke arah melayani konsumen, melibatkan mereka, dan melebihi pengharapan mereka.

Ketrampilan Hirarki. Ketrampilan budaya hirarki meliputi (1) pengelolaan akulturasi, yakni membantu para individu menjadi jelas tentang apa yang diharapkan dari mereka, apa budaya dan standar organisasi, dan bagaimana mereka bisa sangat fir dan situasi pekerjaan; (2) pengelolaan sistem kontrol, yakni menjamin bahwa prosedur, ukuran, dan sistem pemantauan dilaksanakan dan kinerja berada dibawah kendali; (3) pengelolaan koordinasi, 
INOBIS: Jurnal Inovasi Bisnis dan Manajemen Indonesia

Volume 1, Nomor 2, Maret 2018

Dwi Kurniawan; Sumarni

yakni memperkuat koordinasi di dalam organisasi di samping dengan unit-unit eksternal dan berbagi informasi dalam lintas departemen.

\section{Metode Penelitian}

\subsection{Rancangan Penelitian}

Penelitian ini adalah berjenis penelitian survei. Penilitian terutama memiliki tujuan deskriptif dan eksploratif. Tujuan deskriptif dari penelitian adalah untuk mengenali dan mendeskripsikan profil budaya dari organisasi-organisasi yang diteliti untuk melihat kecendrungan-kecendrunganya. Tujuan eksploratif adalah untuk menemukan pola-pola kesesuaian, misalnya antara profil budaya dan ketrampilan manajemen, dan mengenali kesenjangan di antaranya. Unit analisis dari penelitian ini adalah para pengelola dan para karyawan dari usaha-usaha batik yang ada di Kota Jambi.

\subsection{Populasi dan Sampel Penelitian}

Populasi dari penelitian ini adalah kelompok usaha yang tergolong pengrajin batik di kota Jambi. Data pada Tahun 2016 yang bersumber dari Kota Jambi Dalam Angka menunjukkan terdapat 96 unit usaha industri Batik Tulis dan Batik Cap dengan jumlah tenaga kerja sebanyak 695 orang. Responden untuk penelitian ini adalah para pengrajin pemiliki usaha dan para karyawan. Sampel untuk penelitian berjumlah 20 unit usaha.

\subsection{Pengukuran Variabel Penelitian}

Pengukuran budaya organisasi menggunakan instrument yang dikembangkan oleh Cameron dan Quinn(2011), yakni OCAI, yang terdiri enam item, yaitu: (1) karekateristik dominan, (2) kepemimpinan organisasi, (3) manajemen pegawai, (4) perekat organisasi, (5) penekanan strategis, dan (6) criteria sukses, masing-masingnya dengan empat alternative. Selanjutnya, untuk tiap alternative para responden mengalokasi skor 100 poin, tergantung sejauhmana tiap alternative adalah serupa dengan organisasi mereka.

Pengukuran untuk ketrampilan manajemen adalah menggunakan instrument MSAI yang dikembangkan oleh Cameron dan Quinn (2011), yang terdiri dari 12 dimensi, masingmasing adalah tiga dimensi untuk masing-masing dari ke empat profil budaya (Klan, Adhocracy, Pasar, dan Hirarki). Total item untuk pengukuran MSAI adalah sebnyak 60 item, tiap item dijangkar menggunakan skala Likert 5 poin, di mana poin 1 menyatakan responden tidak setuju sama sekali dengan pernyataan, hingga poin 5 yang menyatakan responden setuju sama sekali dengan pernyataan.

\subsection{Metode Pengumpulan Data}

Untuk memperoleh data digunakan metode survey menggunakan perangkat kuesioner terstruktur yang ditujukan pada para responden. Format kuesioner terdiri dari dua bagian utama, bagian pertama menyangkut pertanyaan-pertanyaan umum mengenai karakteristik responden, dan bagian kedua berisi pertanyaan mengenai masalah pokok penelitian. Pengumpulan data dilakukan dengan pertama-tama meminta kesediaan para peserta untuk berpartisipasi dalam penelitian ini, kemudian menyampaikan perangkat kuesioner penelitian 
INOBIS: Jurnal Inovasi Bisnis dan Manajemen Indonesia

Volume 1, Nomor 2, Maret 2018

Dwi Kurniawan; Sumarni

untuk diisi oleh para responden. Pengumpulan data di lapangan dilakukan dengan bantuan para enumerator yang direkrut untuk maksud tersebut.

\subsection{Teknik Pengolahan Data dan Analisis Data}

Statistik deskriptif digunakan untuk menggambarkan karakteristik responden, sampel, dan variabel-variabel penelitian sebagaimana adanya. Karakteristik responden yang akan digambarkan berdasarkan usia, pendidikan, jenis kelamin, jabatan, pengalaman kerja, dan lainnya. Penggambaran secara deskriptif mengenai indikator-indikator dari konstruk-konstruk yang digunakan untuk studi ini adalah menggunakan Organizational Culture Assesment Instrument (OCAI) dan Management Skills Assessment Instrument (MSAI).

\section{Hasil Dan Pembahasan}

\subsection{Karakteristik Responden}

Penelitian ini dilakukan pada beberapa sentra Batik yang terdapat di Kota Jambi yang sebagian besar berada di Kecamatan Danau Teluk dan Kecamatan Pelayangan. Adapun gambaran dari responden yang digunakan dalam penelitian ini adalah sebagai berikut:

Tabel 1

Pengusaha Batik yang Dijadikan Responden

\begin{tabular}{|c|l|c|l|}
\hline No. & \multicolumn{1}{|c|}{ Nama Usaha } & No. & \multicolumn{1}{|c|}{ Nama Usaha } \\
\hline 1. & Batik Nora & 11. & Batik Rogaya \\
\hline 2. & $\begin{array}{l}\text { Batik Tampok } \\
\text { Manggis }\end{array}$ & 12. & Batik Cempaka \\
\hline 3. & Batik Maunawar & 13. & Batik Hj. Annisa \\
\hline 4. & Batik Ariny & 14. & Batik Salma Karim \\
\hline 5. & Batik Rohana & 15. & Batik Sapa \\
\hline 6. & Batik Hasmah & 16. & Batik Royyan \\
\hline 7. & Batik M.Ade Qadri & 17. & Batik Sariyah \\
\hline 8. & Batik Anugerah & 18. & Batik Samina \\
\hline 9. & Batik Zohrif & 19. & Batik Siti Hajar \\
\hline 10. & Batik Rizki & 20. & Batik Suraiyah \\
\hline
\end{tabular}

Masing-masing dari pelaku usaha Batik yang ada di Kota Jambi tersebut diambil satu orang yang dijadikan responden untuk menilai Karakteristik Budaya dan terdapat pembagian menjadi 5 (lima) kelompok yang merupakan pimpinan kelompok usaha tersebut yang dijadikan responden untuk menilai Kecakapan Manajemen.

\subsection{Profil Budaya Organisasi}

Profil Budaya Organisasi menggunakan item-item yang dikembangkan oleh Cameron dan Quinn (2011) yakni The Organizational Culture Assessment Instrument (OCAI). Kuesioner tersebut digunakan untuk mengidentifikasi atau mengukur budaya organisasi yang terdiri dari enam dimensi, yaitu: 1. Karakteristik dominan, 2. Kepemimpinan organisasi, 3. Manajemen kepegawaian, 4. Perekat organisasi, 5. Penekanan organisasi, dan 6. Kriteria 
INOBIS: Jurnal Inovasi Bisnis dan Manajemen Indonesia

Volume 1, Nomor 2, Maret 2018

Dwi Kurniawan; Sumarni

sukses. Berdasarkan data yang diperoleh dengan menggunakan Organization Culture Assessment Instrument, maka diperoleh hasil seperti table berikut ini:

Tabel 2

Budaya Organisasi Saat Ini

\begin{tabular}{|c|l|r|r|r|r|}
\hline No. & \multicolumn{1}{|c|}{ Dimensi } & \multicolumn{1}{c|}{ Clan } & Adhocracy & Market & Hierarchy \\
\hline 1 & Karakteristik Dominan & 39 & 18.5 & 17 & 25.5 \\
\hline 2 & Kepemimpinan Organisasi & 21.25 & 19.5 & 31.35 & 27.5 \\
\hline 3 & Manajemen Kepegawaian & 34.75 & 20 & 19.25 & 26 \\
\hline 4 & Perekat Organisasi & 35.5 & 18.75 & 19 & 26.75 \\
\hline 5 & Penekanan Organisasi & 21.25 & 18.75 & 32.25 & 27.75 \\
\hline 6 & Kriteria Sukses & 37 & 21.25 & 21.25 & 20.75 \\
\hline & Rata-rata & 31.46 & 19.46 & 23.35 & 25.71 \\
\hline
\end{tabular}

Dari tabel 2 diketahui bahwa saat ini budaya yang dominan pada organisasi pengrajin batik di Kota Jambi adalah Budaya Clan dan Hierarchy yaitu sebesar 31,46 dan 25,71. Sedangakan budaya yang bernilai paling kecil adalah Adhocracy sebesar 19.46. Untuk budaya yang diharapkan oleh para pengrajin batik tersaji dalam tabel berikut:

Tabel 3

Budaya Organisasi Yang Diharapkan

\begin{tabular}{|c|l|r|r|r|r|}
\hline No. & \multicolumn{1}{|c|}{ Dimensi } & \multicolumn{1}{c|}{ Clan } & Adhocracy & \multicolumn{1}{c|}{ Market } & Hierarchy \\
\hline 1 & Karakteristik Dominan & 20.75 & 22.5 & 29 & 19.75 \\
\hline 2 & Kepemimpinan Organisasi & 20 & 25.75 & 29.5 & 27 \\
\hline 3 & Manajemen Kepegawaian & 21.25 & 24.5 & 37.25 & 19.25 \\
\hline 4 & Perekat Organisasi & 19.26 & 22.75 & 29.75 & 20 \\
\hline 5 & Penekanan Organisasi & 22 & 18.5 & 30.75 & 22.5 \\
\hline 6 & Kriteria Sukses & 20 & 23.25 & 37 & 22 \\
\hline & Rata-rata & 20.54 & 22.88 & 32.21 & 21.75 \\
\hline
\end{tabular}

Dari Tabel diatas mengenai persepsi budaya yang diharapkan dapat dilihat adanya perubahan harapan yang terjadi dari organisasi ini. Budaya Market menjadi budaya yang dominan yang diharapkan yaitu sebesar 32,21 sedangkan budaya clan bukan lagi menjadi budaya yang dominan diharapkan terjadi yaitu sebesar 20,54.

Terdapat perubahan antara budaya yang saat ini terjadi seperti yang tersaji pada table 5.3 dengan budaya yang diharapkan. Berikut adalah tabel perbedaan proporsi budaya saat ini dengan yang diharapkan:

Tabel 4

Perbedaan Proporsi Budaya Saat Ini Dengan Yang Diharapkan

\begin{tabular}{|c|r|r|r|}
\hline Tipe Budaya & Saat Ini & Diharapkan & Perbedaan \\
\hline Clan & 31.46 & 20.54 & -10.92 \\
\hline Adhocracy & 19.46 & 22.88 & 3.42 \\
\hline Market & 23.35 & 32.21 & 8.86 \\
\hline Hierarchy & 25.71 & 21.75 & -3.96 \\
\hline
\end{tabular}


INOBIS: Jurnal Inovasi Bisnis dan Manajemen Indonesia

Volume 1, Nomor 2, Maret 2018

Dwi Kurniawan; Sumarni

Dari tabel 4 diketahui bahwa tipe budaya yang ingin ditingkatkan proporsinya adalah tipe budaya Adhocracy dan budaya Market yaitu masing-masing bertambah sebesar 3,42 dan 8,86 . Perubahan pada proporsi tipe budaya organisasi usaha kreatif pengrajin batik secara umum memperlihatkan bahwa tipe budaya yang diharapkan akan mendominasi adalah adalah tipe Budaya Adhocracy dan Budaya Market. Sedangkan tipe budaya Clan dan Hierarchy diharapkan untuk diturunkan proporsinya.

\subsection{Profil Keterampilan Manajemen}

Berdasarkan data yang diperoleh dengan menggunakan Management Skills Assessment Instrument Questionnaire (MSAI), maka diketahui bahwa kompetensi managerial pada usaha batik pada saat ini adalah sebagaimana yang terlihat pada tabel berikut:

Tabel 5

Keterampilan Manajerial Manajemen Usaha Batik di Kota Jambi

\begin{tabular}{|c|c|c|}
\hline Kategori Kompetensi Manajerial & Nilai & Klasifikasi \\
\hline $\begin{array}{r}\text { INTERNAL/CLAN } \\
\end{array}$ & 3.13 & Sedang \\
\hline Managing Development of Others & 3.14 & Sedang \\
\hline $\begin{array}{r}\text { Managing Interpersonal } \\
\text { Relationships }\end{array}$ & 3.13 & Sedang \\
\hline Managing Teams & 3.11 & Sedang \\
\hline FLEXIBILITY/ADHOCRACY & 2.97 & Sedang \\
\hline Managing Innovation & 3.07 & Sedang \\
\hline Managing the Future & 2.79 & Sedang \\
\hline $\begin{array}{r}\text { Managing Continuous } \\
\text { Improvement }\end{array}$ & 3.05 & Sedang \\
\hline "EXTERNAL/MARKET & 3.24 & Sedang \\
\hline Managing Competitiveness & 3.05 & $\begin{array}{l}\text { Sedang } \\
\end{array}$ \\
\hline Energising Employees & 3.30 & Sedang \\
\hline Managing Customer Service & 3.36 & Sedang \\
\hline CONTROL/HIERARCHY & 3.11 & Sedang \\
\hline Managing Acculturation & 3.15 & Sedang \\
\hline Managing the Control System & 3.17 & Sedang \\
\hline Managing Coordination & 3.01 & Sedang \\
\hline Managerial Skills & 3.11 & Sedang \\
\hline
\end{tabular}

Dari Tabel 5 memperlihatkan bahwa keterampilan managerial saat ini pada usaha Batik di Kota Jambi yang mendapat nilai tertinggi adalah managing customer service sebesar 3,36, dan energizing employees yaitu 3,30. Sementara itu, nilai terendah ditempati oleh kategori kompetensi managing the future yaitu 2,79. Rata-rata nilai keterampilan manajerial tertinggi ditempati oleh kuadran Matket sebesar 3,24, diikuti kuadran Clan sebesar 3,13, kuadran Hierarchy sebesar 3,11 dan kuadran Adhocracy sebesar 2,97.Secara keseluruhan nilai keterampilan manajerial di Usaha Batik pada saat ini adalah sebesar 3,11 dan berada dalam kategori "Sedang". 
INOBIS: Jurnal Inovasi Bisnis dan Manajemen Indonesia

Volume 1, Nomor 2, Maret 2018

Dwi Kurniawan; Sumarni

\subsection{Pembahasan}

Saat ini tipe Budaya Clan dan Hierarchy masih menjadi ciri khas dalam aktivitas para pelaku bisnis usaha kreatif batik di Kota Jambi. Budaya clan menekankan pada keakraban dan ikatan emosi untuk saling berbagi, sehingga organisasi lebih tampak seperti keluarga yang saling menaungi satu sama lain. Nilai yang diutamakan oleh kultur ini adalah teamwork. Sedangkan pedoman manajemen yang dipakai biasanya berprinsip pada pentingnya partisipasi karyawan atau anggota organisasi. Komitmen karyawan atau kelompok dicapai melalui pengembangan partisipasi karyawan dalam dinamika kerja, proses manajemen, serta pengambilan keputusan. Organisasi diikat oleh loyalitas dan tradisi, pemimpin di dalam kultur ini lebih berfungsi sebagai mentor dengan sifat otoriter yang rendah dan memungkinkan seluruh tim bekerja atas nama kelompok dengan mengesampingkan penonjolan individu.

Selanjutnya Budaya Hierarchy merupakan budaya yang sangat formal dan teratur, dimana setiap aktivitas semua lini manajemen mempunyai sebuah aturan main yang jelas, sesuai dengan apa yang dikehendaki organisasi. Segala sesuatu, mulai dari penentuan kebijakan, pencapaian target strategis didasarkan pada prosedur. Gaya kepemimpinan yang dikembangkan adalah sebagai kordinator dengan fungsi mentoringnya yang kuat dan ketat, sekaligus juga sebagai organisator yang unggul. Organisasi diikat oleh aturan-aturan dan kebijakan formal, dan nilai yang dianggap paling penting adalah efisiensi dan kelancaran jalannya organisasi. Model atau pedoman manajemen yang digunakan biasanya berpusat pada pengendalian dan control yang ketat. Sukses diukur dari produk yang bisa diandalkan, penghematan biaya, dan tentunya kelancaran jadwal.

Tipe Budaya Market menjadi tipe budaya yang paling tinggi proporsi harapan untuk ditingkatkan. Hal ini terjadi karena kultur ini beroperasi pada mekanisme ekonomi pasar, dengan melakukan transaksi-transaksi yang ditujukan untuk menciptakan keunggulan kompetitif. Konsep penting di dalam kultur ini adalah transaction cost. Jadi organisasi lebih berorientasi tehadap hasil, bukan proses. Gaya kepemimpinan yang dikembangkan adalah sebagai competitor dan pendorong yang tangguh. Tujuan jangka panjang dari kultur ini adalah melakukan aktivitas yang kompetitif dan pencapai sasaran yang sudah ditargetkan, sukses dilihat dari pangsa pasar dan penguasaan pasar.

Tipe Budaya Adhocracy ternyata juga dituntut untuk ditingkatkan oleh para pelaku saat ini. Tipe ini merupakan kultur yang sangat dinamis, dijiwai semangat entrepreneursip dan kreatifitas. Nilai yang sangat diutamakan adalah inovasi dan keberanian mengambil resiko. Gaya kepemimpinan yang dikembangkan lebih sebagai innovator, wirausaha, serta visionary leadership. Ikatan yang menyatukan organisasi adalah komitmen terhadap ekperimen dan inovasi. Kesuksesan sebuah kerja organisasi diukur oleh penemuan produk/jasa baru yang inovatif.

Secara sederhana, dari hasil penelitian ini menunjukkan bahwa para pegawai atau para pengrajin menginginkan usaha kerajinan batik ini tidak lagi atau keluar dari anggapan bahwa usaha batik adalah usaha keluarga. Dengan anggapan bahwa usaha batik ini adalah usaha keluarga maka akan sulit untuk mendapatkan ide-ide baru karena ide sangat tergantung dari keterampilan dan pengetahuan dari anggota kelompok-kelompok yang melakukan usaha ini. Perkembangan teknologi informasi yang memunculkan beragam media untuk bersosialisasi dan mencari ide ternyata berdampak pada keinginan dari para pengrajin untuk memanfaatkannya. Motif-motif yang selama ini menjadi bentuk kekhasan dari produk batik di Kota Jambi telah berubah atau dimodifikasi sesuai dengan model-model fashion yang selalu berubah dalam waktu yang sangat cepat. Sebagai contoh, untuk mempertahankan motif-motif yang khas maka para pengrajin saat ini menggunakan bahan-bahan yang bersifat alami seperti 
INOBIS: Jurnal Inovasi Bisnis dan Manajemen Indonesia

Volume 1, Nomor 2, Maret 2018

Dwi Kurniawan; Sumarni

dari kulit pohon, buah, ataupun bahan lain yang diperoleh dari alam dan menghindari bahanbahan yang bersifat murni kimia. Dengan bahan-bahan yang bersifat alami ini produk dengan disain atau motif khas akan terjaga dan dengan harga tinggi yang ditetapkan justru mampu mempertahankan kualitas dan ekskulifitas dari batik ini. Untuk produk dengan pasar konsumen yang lebih mementingkan model atau fashion dengan motif-motif terkini, produsen tetap menggunakan bahan-bahan dasar kimia karena lebih mengutamakan desain yang disukai.

\section{Simpulan}

Dari uraian tentang analisa dan pembahasan maka beberapa kesimpulan yang dapat diambil dari penelitian ini adalah sebagai berikut:

1. Dari 6 (enam) dimensi yang digunakan untuk mengukur profil Budaya Organisasi yaitu Karakteristik Dominan, Kepemimpinan Organisasi, Manajemen Pegawai, Perekat Organisai, Penekanan Strategi, dan Kriteria Sukses ditemukan bahwa aktivitas usaha batik di Kota Jambi saat ini memiliki profil Budaya yang bersifat atau dominan dengan karakteristik Budaya Clan, sedangkan budaya yang diharapkan pada masa yang akan datang adalah budaya yang menekankan pada Market.

2. Untuk Profil Keterampilan Manajemen ditemukan bahwa kegiatan usaha batik di Kota Jambi, para manajemen memiliki kecenderungan melakukan keempat profil budaya, baik budaya yang bersifat Clan, Adhocracy, Market, dan Hierarchy. Nilai untuk profil budaya tersebut adalah sebesar 3,13 atau pada klasifikasi sedang.

3. Bagi pelaku usaha kreatif Batik Jambi di Kota Jambi perkembangan teknologi informasi harus mampu diaplikasikan sebagai media untuk memasarkan hasil produksi. Hal ini menunjukkan perubahan budaya yang bersifat Clan menuju budaya Market. Strategi lain yang dapat diidentifikasi adalah untuk mempertahankan eksklusifitas produk yang dihasilkan, para pelaku usaha dapat menggunakan bahan baku pewarnaan yang bersifat alami.

\section{Daftar Referensi:}

Cameron, Kim S and Robert E. Quinn. 2011. Diagnosing and Changing Organizational Culture based on The Competing Values Framework. Third edition. San Francisco: Jossey Bass

Hofstede, Geert. Culture"s Consequences. 1980. Thousand Oaks, Calif: Sage.

Porter, Michael. Competitive Strategy. 1980. New York: Free Press.

Schein, Edgar H. 2010. Organizasional Culture and Leadership (4th ed.). San Francisco Jossey Bass.

Mullins, L. 1980. Management and Organizational Behaviour. 5th Edition, Portsmouth: Pitman Publishing.

Robbins, S. P. 2003. Organizational Behaviour. New Jersey: Prentice Hall.

Hellriegel, D. Slocum, Jr. J. W. \& Woodman, R.W. 2001. Organizational Behaviour. 9th Edition. Sydney: Thomson Learners, 2001. 